\title{
POSSIBLE OPTIONS FOR ENSURING OF TAX COMPLIANCE
}

\author{
Māris Jurušs ${ }^{1}$, Baiba Šmite-Roḳe ${ }^{2}$, Daiga Zēna-Zēmane ${ }^{3}$, Monta Celmiṇa ${ }^{4}$, Egita Pole ${ }^{5}$ \\ Riga Technical University, Riga, Latvia \\ E-mails:Imaris.juruss@rtu.lv (corresponding author); ${ }^{2}$ baiba.smite-roke@vid.gov.lv; \\ ${ }^{3}$ daiga.zena@gmail.com; ${ }^{4}$ monta.celmina@gmail.com; ${ }^{5}$ egitapole@yahoo.com
}

Received 02 March 2020; accepted 01 May 2020

\begin{abstract}
Tax evasion is one of the biggest challenges for tax administrations around the world. Tax noncompliance leads to a large tax debt in state budgets. Part of these tax debts is impossible to recover, since debtors have neither assets or cash. The aim of this research is to evaluate feasible options to ensure tax compliance. Solutions could be considered in two directions. In short-term it should be considered how to reduce already incurred debts. In the long-term, the segmentation of taxpayers and preventive measures for each segment could be used.
\end{abstract}

Keywords: tax, evasion, debts, compliance, segmentation.

JEL Classification: H26.

\section{Introduction}

Countries face a major dilemma: on one hand, facilitating business start-ups on easier terms, without imposing obstacles, restrictions, requiring equity, guarantees or other financial security to run a business, while at the same time increasing the risk of tax non-compliance. Or, on the other hand, to claim tax guarantees, but thus hindering business start-ups and business development. There is a need for a compromise - a balance between protecting public interests in tax collection and a private initiative for the risk of entrepreneurs.

OECD in its 2017 Tax Administration Report states that data provided by tax authorities of the 55 countries included in the report indicate that the total tax arrears amount is EUR 2.03 trillion, around $40 \%$ or EUR 820 billion are considered collectible (OECD, 2019).

The aim of this research is to find out wether it is possible to create solutions to ensure tax administration by avoiding the occurrence of tax debts and what to do with the existing tax debts.

The goal of this publication is to determine whether it is possible to avert or at least to minimize the occurrence of tax debts, what are the possible solutions to the problem and how to improve tax collection indicators, to review views of international experts and successful practices around the world in fight against tax debtors. The subject of this research is to profile a tax non-payer/debtor created by the authors and a mechanism of segmentation that could be used in the future while defining criteria according to which guarantees or other means must be required from taxpayers to ensure they will fulfill their duties to the state.

Hypothesis 1 of the study: For tax debt recovery, one of the more effective solutions is the segmentation of taxpayers rather than the segmentation of tax debtors, because it allows for preventive control over tax compliance, rather than combating the consequences of a non-payment - debt.

Hypothesis 2: The risks and prevention of tax debts should be treated in the same way as the risks of business default debt, namely, as business partners assess the ability of a partner to settle, as well as their behaviour if a partner fails to pay, such as filing for insolvency and seeking recovery.

Within the scope of this research the authors used the analysis of information, including that in scientific literature and foreign expertise, as well as statistical data analysis. Within the scope of this research the authors concentrated on legal entities to determine are there any regularities and similarities among tax non-payers, what are they, as well as offering possible solutions what authorities can do to minimise the possibility of a tax debt occurrence, especially within VAT area.

\section{Literature review}

Sanctions are not the only or the best solution in fight against tax debts. Outsourcing of tax education, debt re-planning and debt collection should be 
considered. Innovative technologies that, for example, allow tax payments to be made in an easier, faster and simplier way also could prove to be effective. It could be an automatic payment that gives taxpayer an easy way to pay taxes instead of a need to go to tax administration office (Sekyere, 2011; Guenther, 2006).

One of the effective ways to combat tax debtors is to outsource tax debts to private debt collectors. Internal Revenue Service (IRS) of the United States uses this practice. The main arguments in favour of such practice are effectiveness and saving tax administration resources, as well as the fact that capibility of tax authority does not allow to cover all debtors (U.S. Government Accountability Office [GAO], 2019).

Another argument is that taxpayers could avoid paying taxes if they would know that tax authority will not touch them, in such case a gap between calculated and paid sums (tax gap) could increase dramatically. However, the main concern is the fact tax collection is an inseperable part of government functions, therefore it by no means can be delegated to private companies. The opponents of this idea insist such opinion is based on a basis of strong legal precedent, i.e., the existing legislation states a tax authority has a limited tax collection capability. Another big concern is based on the assumption such initiative would possibly prove to be unnecessarily expensive. Finally, the critics of the initiative say it should be abandoned because it opens possibilities for illegal and malicious tax collection practices in the hands of private debt collectors (Guenther, 2006).

Tax debts are accumulated by businesses in relation to their tax obligations, debt management practices in organizations, effects of debt on revenue mobilization and suggestions for proper debt management practices (Sekyere, 2011).

There are different reasons for tax debts: researches show the largest part is a result of tax audits, but it can also arise as the result of tax deferrals, fines for tax debts or late payments (Sekyere, 2011).

Possible solutions might be different, for example, an extension of time to pay or deferral of payment of debts so that the tax can be paid (Sekyere, 2011). The key indicator used to assess tax debt collection performance is undisputed tax debt as a share of net revenue collections, i.e., after tax refunds are paid (Ebraico \& Rua, 2015).

Tax debt management is entrusted to Equitalia, a public company owned by the Revenue Agency and the National Social Security Institute. The latter was set up by the Italian government in 2006 to perform tax debt recovery in the country. Before the establishment of Equitalia, tax debt collection was outsourced to private collectors. Equitalia operates under the control of the Italian revenue agency (Ebraico \& Rua, 2015).

Withholding, advance payments and e-payments are meant to make paying taxes as easy and fraud-proof as possible. They aim at preventing rather than managing tax debts (Ebraico \& Rua, 2015).

Although the disclosure or publication of tax debtors is disputed (Ananda, 2019), it can also be an effective tool. And there is also a question whether tax debt obligations can be transferred to members of family (Norbury, 2019).

A key variable which influences tax debt collection performance is the extent of debt collection powers available to the tax authority, for example, allowing to pay tax debt in parts, create a payment schedule depending on financial circumstances and solvency of each individual taxpayer, use information from third parties (credit institutions, banks), seize debtors' assets, collaterals, use other methods of credit-debit compensation, withold nontax payments government owes the debtor (subsidies, etc.), control participation in public tenders, instigate insolvency, transfer tax debts to directors of legal entities, limit foreign travel of tax debtors, close businesses, revoke licenses, deny access to state services, publish names of tax debtors (Ebraico \& Rua, 2015).

In the US there is a special program for paying tax debts. The service is offering a direct debit payment option to allow taxpayers to pay off their tax debts. The IRS hopes the payment option will make the process somewhat smoother. With a preauthorized direct debit, taxpayers will be able to make one payment or a series of payments on their federal tax debt. With direct debit taxpayers will give their written permission to the private collection agency to authorize a payment on the taxpayer's behalf to the U.S. (Cohn, 2019a, 2019b; California CPA, 2019).

Personal restrictions can also be imposed on tax debtors. For example, US use travel restrictions. Taxpayers late on their taxes are risking to lose their passports. If a taxpayer has a tax debt that exceeds 52000 USD, there are limited chances to avoid further actions from IRS. The choices are: to pay the debt in full or to reduce the amount below the treshold, come up with a sales contract, consider offer of compromise, fulfill settlement with the Department of Justice, demand a court decision, if applicable, or claim innocent spouse relief, if applicable (Moore, 2019). 
While tax authorities have a range of tools to assist with the tax debt collection, New Zealand and Australia tax authorities both hold large amounts of tax receivables. This suggests either that the current tools are not utilised to the greatest extent to reduce tax debt or that the tools are insufficient to achieve the objective of collecting the maximum amount of tax revenue, taking into account available resources (Marriott, 2014).

The research into tax debts in Australia and New Zealand indicates both countries have amassed large amounts of tax debt categorised in their books by tax authority as non-collectable. The rationale for retaining non-collectable debt as part of total debt is not evident. The research suggests that in some cases tax debtors are treated leniently by the tax authorities in New Zealand and Australia. In both countries there are multiple opportunities for tax debt, penalties and interest to be remitted or reduced. When compared with other debtors to the state, tax debtors appear to receive preferential treatment (Marriott, 2014).

There are few differences between a tax debt and other debt. Moreover, there is no clear explanation for the more punitive treatment of business debtors than of tax debtors. Nonetheless, the practice of treating those with debts to the government differently, depending on whether the debt realtes to tax or business, appears to be challenging and changing (Marriott, 2014).

In the attempt to reduce the amount of tax debts certain measures that allow to change user behaviour could be applied, for example, they could be connected to the possibility of paying taxes online (Fonseca \& Grimshaw, 2017).

The main reasons of tax debts can be the worsening of taxpayer's financial situation as the result of financial crisis in a country or a delibarate evasion of taxpayer's obligations. Between the factors that influences a rise of a tax debt must be mentioned the use of tax avoidance schemes, such as reorganisation, dissolution, merger or division (Orlova et al., 2019).

It seems useful to develop an action programme to administer different types of taxpayers and to collect tax debts, resulting as a possibility to avert the rise of tax debts in the future. Also, the use of different classification and segmentation of taxpayers could assist the tax authority (Orlova et al., 2019).

There could be two types of approach - for regulated and unregulated debts. If unregulated (unexpected) debts should be recognized as non-collectable, several options should be used regarding the regulated debts - for example, restructuration, postponed collection or postponed payment (Orlova et al., 2019).

As for the segmentation of taxpayers or debts widely acknowledged mathematically economical methods can be used (Skribans, 2019).

OECD recommends to introduce a special tax debt administration model that would allow tax authorities to be more effective in tax debt management. It does not apply only to the tax debt management, but also to other ways how to decrease tax administration functions, including the transition from reactive processes to proactive common approach with participation from other institutions and third parties, as well as the newest technological tools (OECD, 2019).

\section{Analysis of tax debts in Latvia}

Total tax debt in Latvia on November 1, 2019 was 885.95 million euros or $3 \%$ of GDP in 2018. The largest part $(39 \%)$ of this debt is value added tax (hereinafter - VAT). VAT debt mainly forms as a result of a tax audit. But it cannot be denied the total debt amount is influenced also by companies that participate in VAT avoidance and fraud schemes, declaring payable VAT without intent to pay (State Revenue Service [SRS], 2019a).

Total tax debt in Latvia decreased by $17 \%$ during the year. The recognised result has been achieved by the active introduction of new sufficiently harsh methods. Since 39 per cent of the tax debts have been incurred as a result of an audit, it is essential to understand whether the amount potentially to be invoiced can be recovered. Concurrently with taking of the decision based on the findings of the controlling procedure (review or audit) carried out by the tax authority, as well as taking of the decision to recover late tax payments, the tax authority in Latvia is entitled to apply the following enforcement measures: subjecting the liquid assets owned by the debtor to a lien, making an entry regarding the claim security notation (prohibition or pledge notations) in the Land Register, Ship Register or other property registers, prohibiting the debtor from performing certain activities aimed at evading taxes, subjecting the property located with another person owned by the debtor to a lien.

According to the data collected by the State Revenue Service [SRS], the total tax debt can be structured as follows:

1) current debts $(61.47 \%)$, but actually recoverable are $18.48 \%$, because $42.96 \%$ is out of date or the companies are with no assets;

2) tax deferrals $(6.12 \%)$; 
3) suspended debts $(32.41 \%)$, which are practically imposible to recover, as the debts are owed to insolvent companies (SRS, 2019a).

Total amount of tax debt makes almost $9 \%$ of total tax revenue in 2019. Realistic calculations of collectable tax debt makes only $1.6 \%$ of total tax revenue, which means state and municipality budgets are missing large amounts mainly because of the lack of monetary instruments or assets that state and municipalities could use to recover amounts payable.

While analysing the structure of tax debtors (51 233), processing statistical data and at the same time using the induction method, data reached as the result of segmentation and information received whether correlation between the amount and age of fixed capital of tax debtor, sphere of activity and the amount of tax debt exists, therefore creating a profile of a tax debtor. I.e., by analysing the amount of a fixed capital and the amount of tax debt, as well as the year of establishing a company, declared business activity of each enterprise, companies with tax debts exceeding 10 million euros have been analysed, but companies whose tax debt ranges between one and ten million euros have been analysed by comparing only the amount of their fixed capital against the amount of tax debt. Information about the sphere of activity and the risk of tax debt will be compared with the published information of SRS according to industries that have the largest amount of VAT debt. Taking into consideration initial segmentation, other tax debtors were analysed on a theoretical level, determining whether the amount of tax debt ir larger than the minimal amount of fixed capital in standart cases.

After the analysis of tax debtors according to the amount of their debt it can be concluded that 7 have tax debt exceeding 10 million euros, 113 - between 1 and 10 million euros, 1196 - between 100 thousand and 1 million euros, 8215 - between 10 and 100 thousand euros, 22267 - between 1 and 10 thousand euros (11 332 - debt amount exceeds 2800 euros), and 19425 - between 150 and 1000 euros. In total, 20863 from 51233 or almost $41 \%$ of debtors the amount of tax debt exceeds 2800 euros or the minimal amount of a fixed capital.

The company with the largest tax debt (company registered in 2009 with fixed capital of 2840 euros (close to a minimum)) has caused damages to the state in the amount of 20.9 million euros which is $1.7 \%$ of the total tax debt of the country. The second largest tax debtor (registered only in 2015) is the company with 19.7 million euros tax debt, the third being registered in 2008 and liquidated in 2018 that owes 18.5 million euros to the state. In the fourth place - a company, registered in 2004 with the debt of 14 million euros and registered and paid fixed capital of 297600 euros. In the fifth place company registered in 2007 with the total debt 13487456.05 euros, but registered and paid fixed capital of only 56914 euros. In the sixth place - a company registered in 2014 with the tax debt of 12.5 million euros and registered and paid fixed capital of 3000 euros. In the seventh place, the last company whose tax debt exceeds 10 million euros, is the company registered in 2004 with 11.4 million euros tax debt and registered and paid fixed capital of 4.8 million euros.

The amount of unpaid liabilities of the tax debtors whose debts exceed 10 million euros makes almost 9 per cent of the total amount of tax debts and around 1.2 per cent of the total tax receivables. 113 legal persons has a tax debt between one and ten million euros, however, for 75 out of 113 debtors the tax debt does not exceed two million euros. Only 9 out of 108 companies' registered and paid fixed capital reaches or exceeds the amount of tax debt, registered and paid fixed capital of other 99 companies does not reach or exceed the amount of tax debt, just like in the case of seven largest tax debtors, even though there are companies between these debtors whose registered and paid fixed capital is in millions (3.5 and 5 million euros). Also, only in few companies fixed capital several times exceeds the total amount of a tax debt, usually when the fixed capital is larger than the total amount of a tax debt, it is just a little above the total amount of a company's tax debt.

Few of the 108 companies analysed previously has a registered and paid fixed capital of just one euro, however, there seems to be no tendency for companies with a small fixed capital to be among the largest tax debtors. However, other type of tendency can be observed - in most cases the registered and paid fixed capital is up to 3000 euros, i.e., in the amount of minimal fixed capital or in the amount that is close to it. That creates an assumption companies are not interested to increase their fixed capital in the case their activities increase.

A small number of 108 companies has a registered and paid fixed capital in the amount of up to 10000 euros, and only around 10 per cent of the analysed companies have fixed capital of tens of thousands of euros and that does not reach the total amount of a tax debt.

While analysing the total amount of tax debtors, it can be asserted that 20863 of 51233 debtors the amount of tax debt exceeds 2800 euros or the minimal amount of fixed capital. I.e., almost 41 per cent of debtors the debt amount possibly could be 
higher than registered and paid fixed capital, in which case it can be non-collectible if a debtor does not have any other assets.

Taking this into consideration, it can be concluded - smaller the amount of company's tax debt, larger the possibility its' fixed capital will reach the amount of debt. For example, if the debt amount is 2800 euros, which is the minimal amount of a fixed capital, most likely the amount of the fixed capital will reach the amount of a debt. In cases where company's tax debt reaches tens of thousands of euros, there is a real chance the company's fixed capital itself will not be sufficient to cover tax debts.

Here one of the aspects of the problem takes shape - a company has no assets and/or monetary means to where the debt collection can be addressed to.

While analysing the age of debtors it can be concluded there is no corelation between company age and amount of tax debt - a debt of several millions can occur to two year old company, as well as to one more than ten years old.

The seven largest tax debtors do not come from one industry, but analysis of industries and types of businesses where the largest VAT debts are imposed, several regularities can be seen - companies with the largest debts come from industries with the largest debts. What concerns the industries of debtors, there are no established similarities - types of businesses and industry is not a common factor among the tax debtors. Of course, it cannot be denied the fact there are industries that bear a higher risk by having more tax debts than others (for example, car sales, crop sales, etc.). Sometimes in these high-risk industries reverse VAT is applied. Therefore it is sufficient to conclude there are no direct regularities between the industry and type of business - any company in any industry can have a tax debt.

While creating a certain profile of a company tax debtor we can conclude that in most cases it is a company whose tax debts exceed its' registered and paid fixed capital, often such company is declared insolvent and, in most cases (if not always), it has been a subject of a tax audit. But there is no evidence regarding corelation between the age of a company, amount of a tax debt, represented industry and/or type of business.

\section{Tax debts recovery}

Tax administrations around the world are looking for the most effective ways to collect tax debts. They need to seek even more innovative, strategic, coordinated ways to prevent an increase in tax debts and reduce debt collection costs.
In practice the approach to prevent tax debt growth could be similar, as it used to be in the case of tax evasion or avoidance. The tax administrations approach to debt recovery may be the same as the one witch was designed as the approach for fighting against tax terrorism: a mitigation of the consequences or a prevention of the causes (Jurušs, 2017).

Generally, there can be two approaches used to limit the occurrence and increase of tax debts and to improve the efficiency of tax debt recovery. First, the consequences of tax debt should be mitigated. This task involves tax debt structuring or recognising debt which is not economical to recover, maximise collection before enforcement measures and effective use of enforcement tools.

Second, the causes of tax debt occurrence should be prevented. This is a long term issue and may require a lot of resources (available technology tools, including enhanced analytical abilities) and activities (strategic approach to ensure taxpayer segmentation by characteristics and greater use of proactive engagement).

The OECD has recognized (OECD, 2014) that certain aspects need to be addressed in order to establish an effective tax debt recovery policy:

- Improved analytical processes - tax administrations can no longer afford to treat all tax debtors in the same way. Improved analytical tools make it possible for the tax administration to use all the information to address the debtor with the most appropriate way;

- Strategies for an appropriate treatment of tax debtors - tax debt recovery processes should be able to choose from a range of instruments, ranging from "lighter" created for preventive purposes (such as protecting the taxpayer from incurring debts) up to the harsh measures of tax recovery;

- Specialised call centers - this research evaluates several such strategic units;

- Organization - process in itself. This research points out that debt collection is a specialist function and should be organized. Precise segmentation of taxpayers is needed, as is a systematic approach to data analysis;

- Tax debtors who went abroad - whereas the number of persons moving freely, as well as companies, is increasing, including the number of debtors who have left the home country, it is becoming more challenging to find solutions, opportunities and 
tools to tackle this problem. The international flow of information exchange needs to be improved.

Countries mostly use similar solutions to reduce tax debts or to avoid them at all (OECD, 2014). For example, Australian tax office (ATO) has stated "the older the debt, the harder it is to recover". The ATO's strategy is a differentiated approach to taxpayers - a tougher approach for taxpayers who take no action to manage their debts or against those who are consistently and knowingly engaging in tax evasion or tax avoidance activities. The ATO also applies appropriate strategies to those with short-term financial difficulties working with the ATO to address their tax liabilities. These taxpayers are offered a targeted support by the ATO, which includes costumized payment arrangements, reduced penalty rates, as well as full or definitive exemption from payment of certain charges. The ATO draws attention to the fact that most tax debts are incurred by small businesses, therefore, it focuses on this sector to manage the risk of tax debt even before the debts are incurred, having regard the location of the taxpayer and the history of tax compliance. As a preventive measure, the ATO identifies individualized assistance visits. In addition, as stated in the OECD report, the ATO has a special department for debt recovery, the call center who can call the taxpayer for a specific interviews with the tax administration at a specified time. The ATO also outsources its debt collection activities.

A similar mechanism is used in Latvia - after the tax administration has done everything within its capability to recover tax debts, it is transferred to a sworn bailiff for further recovery (State Revenue Service, 2019a).

In the United Kingdom, like in Australia, the debt management strategy involves taxpayer differentiation and segmentation by debt, for example, by the value (amount) of tax debt and the behavior of a group of taxpayers, adjusting certain actions to each group. In Canada, too, taxpayers are differentiated according to taxpayers' behavior and the conditions their debts are incurred.

In France, a tailored risk-based strategy has been put in place to reduce tax debts (OECD, 2014). In this country, taxpayers are segmented based on taxpayer's behavior (such as whether or not it's their first tax debt), considers the debtor's sector of activity (industry, trade, security sector, etc.) as well as the type of activity. Thereafter, based on this information, the tax recovery policy is adjusted on the basis of the costs of the selected debt recovery instrument and the size of the tax debt.
In Latvia, a taxpayer may request a delay of up to 5 years no later than 3 days before the due date for payment. In Latvia tax administration has the right to impose the liability of the legal person's late tax payment on the board members of legal persons. In Australia, this instrument has been in place since 1993, while in Latvia, although regulation has been in place since 2016, there are only a few isolated cases where an official has been held liable for a legal person's tax debts. The problem in this case is the fact that the law lays down criteria that must all be met at the same time in order to be eligible for the particular tax debt recovery mechanism.

Attention should also be paid to so-called tax amnesty measures where, under certain conditions, taxpayers can cover their outstanding tax liabilities. The tax amnesty is well known and is used in various ways not only in Latvia, but also in other countries such as Turkey, Nigeria, Ghana. The unifying aspect is that in all cases the tax amnesty is granted for a limited period only. Countries are addressing the tax amnesty programs as part of their fiscal policies. Tax amnesties generally allow individuals and/or companies to cover late tax payments without imposing any sanctions (Alm et al., 2014).

In Nigeria, the tax amnesty program provided for a nine-month period during which taxpayers could declare their unannounced assets and income from the past six years. The taxpayers who volunteered and participated in the tax amnesty program received a number of benefits, such as immunity from prosecution and tax audits, including the lifting of sanctions and interest payments, and taxpayers also had the option of temporarily distributing the amount of tax due, not exceeding three years (KPMG, 2017).

In Ghana, the nature of the tax amnesty program is similar to what is being implemented in Nigeria. In particular, the scheme afforded individuals the opportunity to voluntarily file a tax declaration and to pay the relevant taxes on all previously undeclared taxes, without paying penalties or interest that would otherwise have been due for default (Ghana Revenue Authority, 2017).

In Turkey, on the other hand, this program is being implemented in a number of different ways. For example, it provides for the possibility to restructure tax debts by providing a more advantageous way of determining interest for taxpayers and providing for a $90 \%$ exemption from interest payments if the principal is paid in one installment. Various "bonuses" are also envisaged when litigation is taking place between a person and the tax administration (in which case the amount of the gain de- 
pends on the stage of the proceeding and other factors), and when the tax administration is still conducting a personal check. It also provides for the possibility of declaring previously unreported transactions at lower interest rates than usual. By increasing the taxable amount previously declared, it is guaranteed that no further checks will be carried out by the tax administration and that additional taxable amount may be paid by dividing the payment of the debt within the deadlines for a specified period (PwC, 2018).

Tax amnesty was also used in Latvia in 2012 and 2017 (SRS, 2019a).

The current issue is benefits of a tax amnesty for tax revenue. In the short term, tax amnesty can be used to generate tax revenue, but on the other hand, tax amnesty measures cause real losses as the state does not receive most of its tax payments (Sa'adah, 2018).

Tax amnesty measures are seen as contradictory income-raising mechanisms. It also calls into question the long-term impact of the tax amnesty on revenue, in particular for honest taxpayers who deplore the special tax regime for non-taxable persons (Alm et al., 2014).

For example, Nigeria regained 98 million USD. By comparison, Nigeria's GDP in 2016 reached 337 billion USD (Nliam, 2018).

In January 2018, the United States Congress decided to begin the process of limiting the tax debtor's right to use his passport (Sheppard, 2018). In the USA serious tax violations may result in refusal to issue a new passport or already issued passport may be revoked (Erb, 2017). Such treatment of individual taxpayers and the prohibition of international travel derive from United States law. The United States tax administration, IRS, believes that this will certainly bring these taxpayers' attention to their outstanding liabilities. That limit the application of certain criteria, including outstanding tax debt of more than 50000 US dollars. This threshold for unpaid tax debt is a variable subject which will increase each year as a result of inflation.

The Estonian tax administration has developed that it can provide electronic and automatic (by credit institutions) seizure of the debtor's funds in the e-environment. Similarly, the solution implemented by the Estonian tax administration has ensured that the debtor cannot open new accounts with other credit institutions without applying collateral to them.

\section{Taxpayer segmentation}

The main issue is how and what to do to reduce tax debt. Tax administrations usually do not have the capacity to apply control measures to each risky taxpayer, therefore they must seek new effective methods that could stimulate voluntary tax compliance.

Taking into account previously obtained data it is necessary to identify techniques to, first, minimise the amount of arising tax debt and, second, to maximise recoveries.

One way to reduce the number of dishonest taxpayers that incur tax debt is through the taxpayer rating system. The main purpose of a rating process is to create a comprehensive evaluation of complex systems. The goals of this system are to inform taxpayers of how they compare to trends in the country, promote taxpayer compliance and provide honest taxpayer with a tool by which they can present their good reputation to business partners (IOTA, 2019).

At the same time, such automated taxpayer analysis is a good way to assess what actions on the part of a tax administration would be required to take in relation to a taxpayer. For a "good" taxpayer it is certainly not necessary to apply as strict rules as someone already recognised as risky.

Latvia has also introduced a taxpayer rating system which, when analysing specific data (tax debt, wages and others, including the risk assessment of VAT transactions in the future), gives an assessment of each company, - closer it is to $100 \%$, better the taxpayer is considered (SRS, 2019b). The taxpayer rating system analyzes five different aspects (see Figure 1):

- Credibility and violations in registration data reflect the reputation of the company and its owners;

- Wages reflect the ability of the business to atract a high-quality work force;

- Financial indicators describe the profitability and solvency aspects of a business;

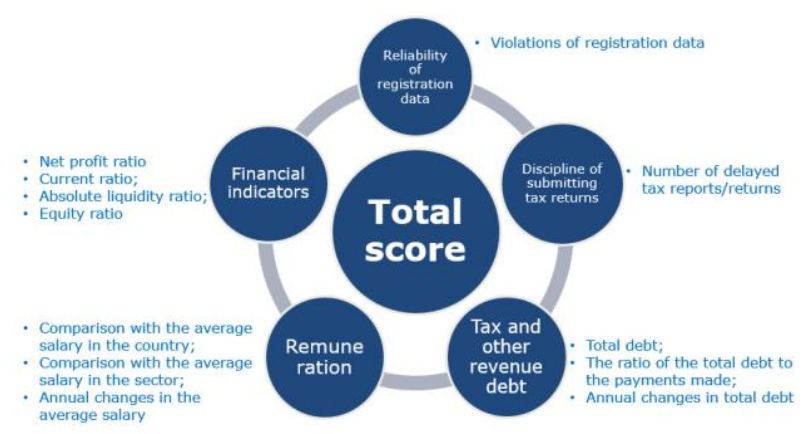

Figure 1. The taxpayer rating system in Latvia (SRS, 2019b) 
- Tax payment discipline is assessed by a) total amount of debt at the end of a previous month, $b$ ) ratio of total debt and payments, c) changes in total debt (previous month's end debt compared to the debt on the corresponding date of the previous year);

- Tax reporting discipline.

Latvia also offers "In-depth Cooperation Programme" where taxpayers have been divided in three levels (gold, silver and bronze) based on defined 15 criteria (for example, annual net turnover, payments into the state budget, employee average salary). The programme advantages include shorter waiting times for answers and consultations, VAT rebates and receipt of permits for commercial activities with excise goods. In addition, gold members enjoy quicker repayment of eligible expenses, debt repayment, cash register service and security for excise goods. Other benefits vary according to the level. Thus companies that do not participate in the "In-depth Cooperation Programme" and fall into one of the "risky" sectors should introduce additional conditions, control measures to reduce, for example, the risks of VAT debt.

However, the SRS has launched a further division of taxpayers. The SRS's new strategy for 2020-2023 foresees the introduction of taxpayer segmentation. The goals of taxpayer segmentation are: to recognize taxpayer type by tax discipline and to develop tax administration tactics based on taxpayer type. Depending on the taxpayer's eligibility for a particular segment, an appropriate approach will be offered (for example, consultation or audit, tax returns or economic activity suspension).

The best practice of the client relationship management in business should be adjusted and implemented in the public sector, also for a tax administration. To facilitate loyalty of taxpayers and promote paying taxes, it is necessary to continue considering the advantages for key account taxpayers, for example, by reducing the bureaucracy of public procurement and others (Jurušs \& Kalderauska, 2017).

One of the solutions could also be to extend the scope of a reverse charge mechanism of VAT, although it should be noted that this could only temporarily limit VAT fraud as fraudsters would target other industries (Jurušs, 2017).

If the fixed share capital of a taxpayer is minimal or taxpayer does not own a property, then a security could be required to certify the company will settle a possible tax debt, as in the case of customs procedures when importers provide customs' guarantee.
The state should think about changes to regulatory framework in this area. In some cases, it should be compulsory for companies to increase its' share capital, for example, when achieving a certain turnover over a certain period, as well as where it previously had a tax debt or the tax administration has identified any risks when taking control measures, it is imperative that the share capital be increased in order to obtain an advantage from the tax administration.

To reduce the risks of tax evasion, the authors offer to use algorithm (see Figure 2) how to make assessment of taxpayers capability to cover tax debt.

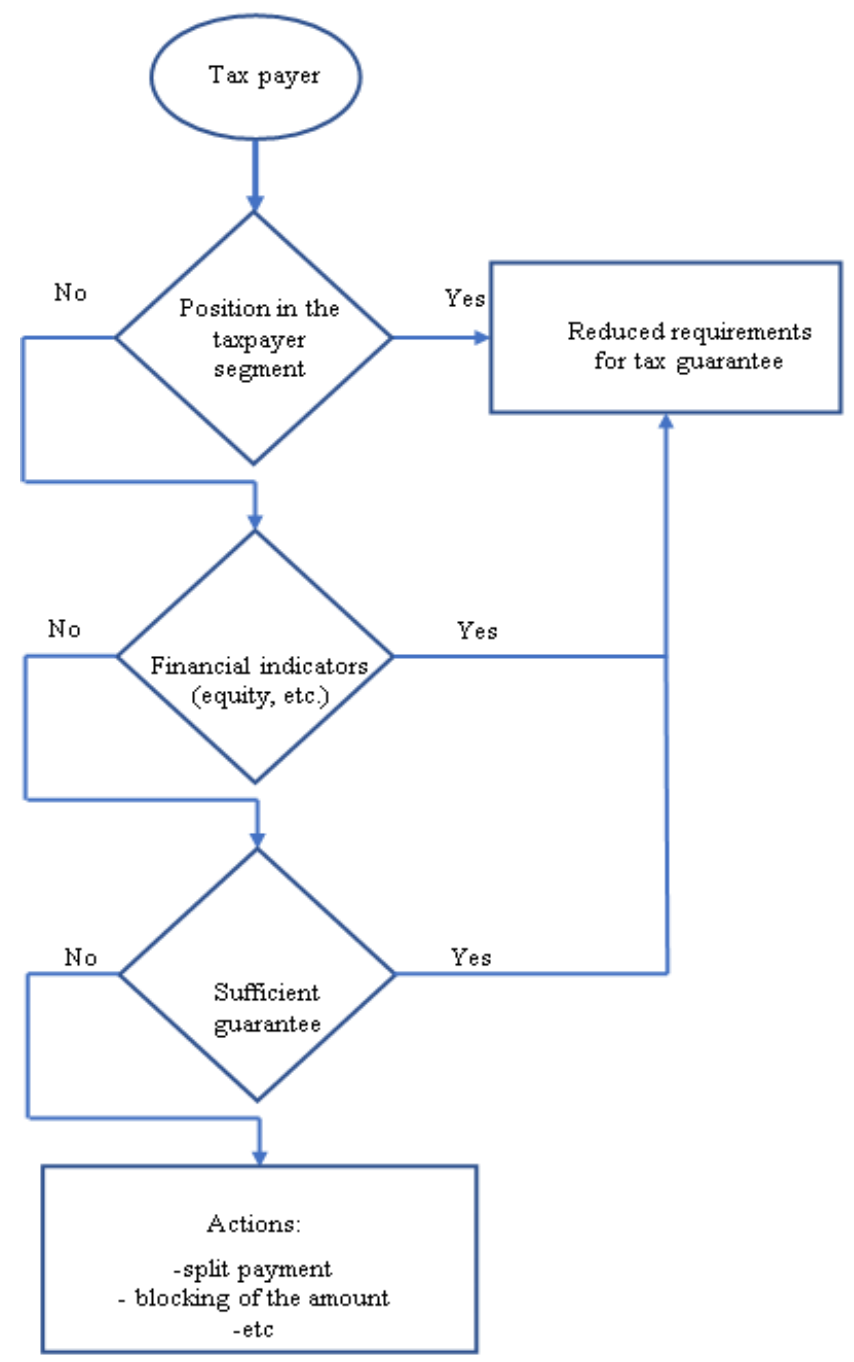

Figure 2. Algoritm of assessment of taxpayer capability to pay taxes (source: the autors)

The process of assessment could start with a check of taxpayer's position in the taxpayer segment. If it is a trustworthy taxpayer, no actions are needed and taxpayer could proceed with transaction. If not, the next step could be the evaluation of actual financial indicators of a taxpayer - whether 
they are sufficient (for example, whether the total liquidity ratio is within the optimal limits, such as the ratio of financial equilibrium or the total amount of the company's creditors to the company's equity, what is the ratio of all liabilities). In cases where financial indicators are satisfactory, meeting certain requirements, reduced requirements may be applied. If the financial indicators are not satisfactory - they do not meet certain requirements: in order to apply reduced requirements, a sufficient guarantee must be provided to demonstrate the company will be able to settle its' obligations and pay taxes.

Reduced requirements would include more favourable conditions and more favourable treatment of tax administration towards the taxpayer, particularly when it has incurred a VAT debt. At the same time, reduced requirements would ensure that no enforcement provision is applied, as well as the possibility that, if necessary, the tax administration would rather take a favourable decision, such as granting an extension of the period of payment. Similarly, reduced requirements include allowing VAT to be paid in "normal order" rather than in reverse charge or split payment, to be paid into a VAT invoice account rather than into an account specifically created by the tax administration, faster reimbursement of VAT overpayment or referral to other charges.

These steps need to be taken by analysing each particular taxpayer so that the services provided by tax administration are not favourable to risky companies. It is not always the capacity of tax administrations to carry out an in-depth analysis, or the tools used (IT systems) do not allow an overview of a taxpayer.

Therefore, a more general solution could be used (see Figure 3) - a method of unified taxpayer segmentation tool for tax administrations, which would divide companies into groups not by size (big, medium, small), but by common criteria, depending on company's behaviour as a taxpayer. It could be a model of seven segments (see the figure), in which the breakdown is based on series of criteria:

1. Trustworthy - taxpayers with excellent discipline.

2. Need support - taxpayers with good tax discipline.

3. Need monitoring - tax risks have been identified.

4. Unregistred - conducts commercial activity, but not yet registered as a taxpayer.

5. Low sustainability - economic activity is not sufficient to meet tax obligations, unstable employers.
6. Restrictable - registered without an intention to pursue an economic activity or reveal significant irregularities.

7. New businesses - information is available only for owners and officials.

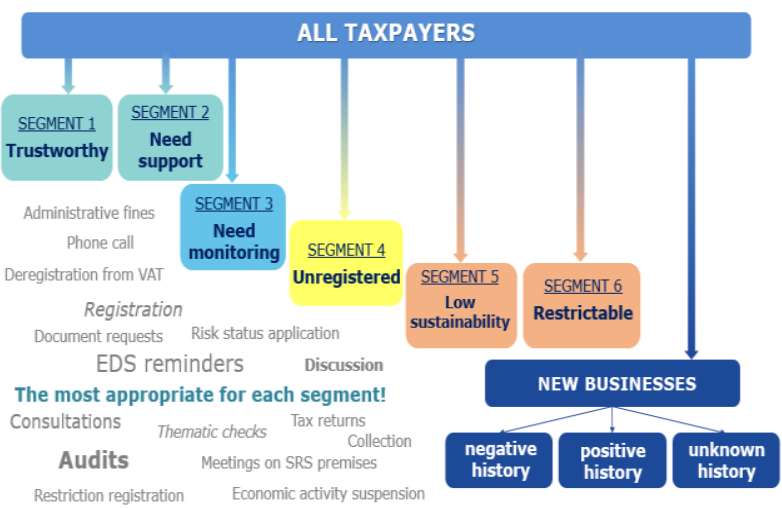

Figure 3. Tax payers segmentation in Latvia (SRS, 2020)

As a result of the segmentation, companies would be divided into groups, and any tax administration official would be able to apply their behavior according to the action model for a particular segment. This requires a great efforts for preparation of such segmentation. A macro-analysis would be needed to identify budget contributions or tax losses of various taxpayer segments and to follow tax payment improvement indicators, as well as a micro-analysis to create taxpayer categories based on a long-term tax payment history. The aim is unified communications and services strategy with clients - one face on all channels.

\section{Prevention of tax non-compliance}

In order to fight tax evasion we should tackle the causes of it. There are several solutions how to change the VAT system: by introducing reverse charge payment, split payment or other methods.

One of the solutions to fight VAT fraud is socalled split payment method. After receiving an invoice a buyer transfers the necessary amount without tax to the supplier's bank account, while VAT is paid into the tax administration's account (or the supplier's account to which the tax administration has access). This eliminates the risk that such taxpayer, the issuer of the invoice, will disappear with the unpaid tax (Michalik, 2017).

Such VAT arrangements have been introduced in Poland as of 1 April 2018, and similar in Italy. In Italy, VAT is paid into a separate and closed tax administration account rather than being paid to a supplier when supply is made to the public sector. The 
introduction of such system in Italy has resulted in a faster overpayment process (Mitran, 2017).

In Poland, the split payment account will operate in such way that it can be used to pay the input tax or to pay VAT to tax authorities. Other transfers from a given account will require an authorisation from the tax administration that can be granted within 60 days of filing an application. In Poland, a variety of incentives have been used to promote this method of payment, for example, if VAT is paid to the tax administration from a VAT account, there is a possibility to obtain a slight reduction in VAT due (Euromoney Institutional Investor PLC, 2019).

In Estonia, it is stipulated that companies are prohibited from lending in certain cases. For example, it is prohibited to provide a loan to company's shareholder more than 5\% from the share capital.

In Estonia, $10 \%$ of all companies pay $90 \%$ of all taxes (IOTA, 2019). At the same time, Estonian tax administration also highlights the need to know and understand the behaviour of its customers, taxpayers, in order to support and promote the growth and sustainability of businesses. It follows from this point of view that tax payments are closely linked to taxpayers' morality, perceptions and accountability.

Tax morale is taxpayer's motivation to respect the tax compliance. Researches have shown that trust is negatively linked to tax avoidance and low trust in tax authorities is associated with higher tax evasion. Tax morale is higher in countries with higher control of corruption and lower bureaucracy (Wadesango et al., 2018).

In case of a tax debt, tax administration has the right to file an application for insolvency proceedings as a creditor under certain preconditions, the legislator should also think proactively about how to further protect the interests of tax administration as a creditor by limiting the ability of the company to carry out activities that may reduce the capacity of tax administration to claim possibilities for recovery. For example, prohibit for tax debtors to use debt as commercial custodians or to secure other pledges or ban marks on their own property without authorisation by tax administration.

The problem also arises in cooperation between tax administration departments: either risk information is not released and received in an appropriate time, or it is not processed in a way to avoid a possibility the declared payment is turned into a tax debt.

Attention should be paid to taxpayers whose declared VAT in the monthly VAT statements does not represent significant amounts, while suddenly the VAT declared by the taxpayer amounts to several hundred thousand (in terms of atypical amount). If there are signals of this kind, it is necessary to contact the taxpayer or to organise tax control measures. Active and immediate action is required to eliminate the likelihood this declared VAT payment is not paid in time and does not add to tax debt structure. This means control in real time and advanced tax risk management system should be in place.

Much depends, however, on the perception and attitudes of taxpayers. From a public standpoint, it is clear there are large numbers of taxpayers who believe that paying taxes is unnecessary. Until taxpayers change their attitude or, more likely, the state changes its' attitude, tax debts will continue to increase and influence honest taxpayers.

In Latvia, it is stipulated that the official of a company can also be responsible to the debts of the company with his or her personal property. A more proactive application of this framework, including through amendments that would make it easier to apply, would probably be one of the best and most effective ways of achieving a reduction in the amount of existing tax debt by increasing the revenues of the public budget, in cases where tax debt has been created because of dishonest taxpayers. This is due to the fact that individuals (company officials), as opposed to companies with tax debts, which are often founded to only participate in different schemes and who do not belong to them, are more likely to have property, including the wage to which enforcement could be directed (to carry out recovery). Actions must also be taken to prevent such individuals from becoming active in the commercial legal environment in the future, by creating and representing new companies, by increasing the amount of tax debt.

In cases where a tax debt has been created by persons who might be called to be responsible, the application of various amnesty measures could help to reduce the amount of tax debt while also increasing the revenues of the state budget, assuming that individuals themselves would be interested in settling their obligations.

Finally, as a solution to reduce the amount of a tax debt a release form tax debt (tax amnesty) could be considered.

\section{Conclusions}

The most important thing is the prevention of avoiding the creation of a large tax debt obligation. Taxpayers' motivation to pay taxes, such as the in-deep 
cooperation programme, is one of the preventive aspects.

More attention and resources should be shifted to the issue of taxpayer segmentation by applying tax debt risk management applied to each group of taxpayers. In this context, a requirement to increase a fixed share capital as the turnover increases or other national financial requirements should be established.

\section{References}

Alm, J., Martinez-Vazquez, J., \& Wallace, S. (2014). Do tax amnesties work? The revenue effects of tax amnesties during the transition in the Russian Federation. Economic Analysis and Policy, 39(2), 235-253. https://doi.org/10.1016/S0313-5926(09)50019-7

Ananda, A. (2019). Tax debt disclosure. Taxation in Australia, 54(4), 164.

California CPA. (2019). IRS Private Debt Collection Program Brings in $\$ 130.6 \mathrm{M}$. California CPA, 87(10), 9. http://californiacpa.calcpa.org/?issueID= 93\&page ID $=10$

Cohn, M. (2019a, April 29). Private agencies collecting less than $2 \%$ of tax debts. Accounting Today. https://www.accountingtoday.com/news/privatetax-debt-collectors-collecting-less-than-2-of-debtssays-gao

Cohn, M. (2019b, October 8). IRS adds new payment option to private debt collection program: The service is offering a direct debit payment option to allow taxpayers to pay off their tax debts. Accounting Today.

https://www.accountingtoday.com/news/irs-addsnew-preauthorized-direct-debit-payment-optionto-private-debt-collection-program

Ebraico, M., \& Rua, S. (2015). An assessment of the performance of the Italian Tax Debt Collection System (No. 53). Directorate General Taxation and Customs Union, European Commission.

Erb, K. P. (2017, February 3). Fix the tax code friday: Revoking passports for unpaid tax debts. Forbes. https://www.forbes.com/sites/kellyphillipserb/2017/02/03/fix-the-tax-code-friday-revoking-passports-for-unpaid-taxdebts/\#745e4e675559

Euromoney Institutional Investor PLC. (2019). Poland: Split payment in Poland is about to be launched. International Tax Review,.

Fonseca, M. A., \& Grimshaw, S. B. (2017). Do behavioral nudges in prepopulated tax forms affect compliance? Experimental evidence with real taxpayers. Journal of Public Policy \& Marketing, 36(2), 213-226. https://doi.org/10.1509/jppm.15.128

Ghana Revenue Authority. (2017). Guidelines on the tax amnesty act (Act 955).
Guenther, G. L. (2006). The internal revenue service's use of private debt collection agencies: Current status and issues for congress. Congressional Research Service.

IOTA. (2019). Taxpayer rating system in Latvia. Tax Tribune magazine: $38^{\text {th }}$ edition. IOTA, Budapest.

Jurušs, M., \& Kalderauska, S. E. (2017). Possible implementation of key account management principles in tax administration. Acta Prosperitatis, (8), 24-118.

Jurušs, M. (2017). Criteria for defining tax evasion as tax terrorism. Economics and Business, 30(1), 102112. https://doi.org/10.1515/eb-2017-0009

KPMG. (2017). Nigeria: Tax amnesty program. https://home.kpmg/content/dam/kpmg/ch/pdf/nigeria-tax-amnesty-factsheet.pdf

Marriott, L. (2014). Tax debt management in New Zealand and Australia. Journal of Australasian Tax Teachers Association, 9(1), 1-23.

Michalik, T. (2017). How the European Commission and European countries fight VAT fraud. BRE BankCASE Seminar Proceedings, (147), 10-33. https://doi.org/10.2139/ssrn.2996600

Mitran, D. (2017). European trends in split vat. Internal Auditing \& Risk Management, 12(4), 43-50.

Moore, D. T. (2019, April 1). Don't let clients get grounded by a tax debt. Tax Adviser, 1-3.

Nliam, A. E. (2018, June 7). Nigeria recovers \$98 million with tax evasion amnesty. Voice of Nigeria.

Norbury, M. (2019). Tomaris and the portable tax debt. Taxation in Australia, 53(8), 446-448.

OECD. (2019). Tax debt management maturity model. OECD Tax Administration Maturity Model Series. Paris.

OECD. (2014). Working smarter in tax debt management. OECD Publishing. https://doi.org/10.1787/9789264223257-en

OECD. (2017). Tax administration 2017: Comparative information on OECD and other advanced and emerging economies. OECD Publishing. https://doi.org/10.1787/tax_admin-2017-en

Orlova, M. E., Nasyrova, V. I., \& Salmina, S. V. (2019). Tax debt and ways of reducing it. $3 C T I C$, Cuadernos de desarrollo aplicados a las TIC (Special Issue), 330-345.

https://doi.org/10.17993/3ctic.2019.83-2.330-345

PwC. (2018). Tax amnesty. https://www.pwc.com.tr/ en/Bulletins/tax/2018/tax-amnesty.pdf

Sa'adah, N. (2018). Tax amnesty policy as an effort to improve state revenues and investment growth. In IOP Conference Series: Earth and Environmental Science (Vol. 175). IOP Publishing. https://doi.org/10.1088/1755-1315/175/1/012206

Sekyere, E. O. (2011). Assessment of value added tax debt management of firms in tamale metropolis. (Doctoral dissertation). Institute of Distance Learning, Kwame Nkrumah University of Science and Technology. 
Sheppard. H. E. (2018). IRS Starts depriving tax debtors of passports in 2018: New Guidance about code sec. 7345 and future tax court disputes. Journal of Tax Practice \& Procedures, 20(1), 37-49.

Skribans, V. (2019). Used-car market dataset for Latvia 2018. Data in Brief, 22, 859-862. https://doi.org/10.1016/j.dib.2018.12.075

State Revenue Service. (2019a). Tax debitors.

State Revenue Service. (2019b). Taxpayer rating system. State Revenue Service. (2020). Taxpayer segmentation.
U.S. Government Accountability Office. (2019). Tax debt collection contracts: IRS analysis could help improve program results and better protect taxpayers (GAO Reports, pp. 166-219).

Wadesango, N., Mutema, A., Mhaka, C., \& Wadesango, V. O. (2018). Tax compliance of small and medium enterprises through the self-assessment system: issues and challenges. Academy of Accounting \& Financial Studies Journal, 22(3), 1-15. 